\title{
Analysis of Performance Appraisal System of Editorial Staff in Newspaper Group---------Take 'Changchun Daily' as an ExampleLiya Yao
}

\author{
Jilin Engineering Normal University
}

Keywords: Changchun daily; Performance appraisal; News editorial; Theoretical significance

\begin{abstract}
In the context of global marketization, the competition of the media industry in our country is becoming more and more intense. Therefore, how to establish a scientific and reasonable performance appraisal system is not only directly related to whether the enthusiasm and creativity of the editorial staff can be fully exploited, but also plays an important role in the effective participation of newspaper media in market competition. In this paper, we will take Changchun Daily as the object of study, analyze its existing performance appraisal system and put forward improvements and suggestions further. This study possesses a positive theoretical significance.
\end{abstract}

\section{Introduction}

With the continuous development of large data and media integration, new media and traditional media gradually show the trend of cooperation, sharing and integration, the transmission style began to show a variety of selection, Changchun Daily newspaper group as the nature of the public institution has begun to face unprecedented impact and challenges. As with all industries and enterprises, Changchun daily newspaper group must devote considerable attention to human resources, only can they maintain a good competitive advantage in the new environment, break the bottleneck of the development of enterprises and achieve industry breakthrough. Scientific and reasonable performance appraisal system as an important part of human resources management, not only determines the ability of enterprises to attract, encourage and retain talent, but also increasingly become an important task and mission of Changchun Daily daily management.

\section{An Overview of the Changchun Daily}

The Changchun Daily is a comprehensive newspaper with the largest circulation, the widest coverage and the highest circulation rate in Changchun. It is founded on November 15, 1945 and formerly known as Changchun News. The Changchun Daily newspaper group was established on December 16, 1999. As a daily newspaper issued in the six districts of Changchun and the jurisdictions of the four cities (counties), Changchun Daily not only has the solemnity of the party newspaper, but also has the characteristics of the evening newspaper. Therefore, it has a wide range of readers, welcomed by the people of all walks of life.

\section{The Analysis of the Current Situation of Performance Appraisal of Changchun Daily}

In the 1990s, like most of the organs of the newspaper and party newspaper, Changchun Daily editorial staff did not clear the assessment criteria and performance appraisal indicators, but examine the quality and ability of editing staff from moral, capacity, diligence, performance and other aspects. In twenty-first Century, with the increasingly fierce competition of economic globalization, integration of media and digital media have gradually become the mainstream media. Changchun Daily originated as an official newspaper, realized that the traditional media channels had been unable to meet the diverse needs of people to obtain information on the way, and this would require News Department performance appraisal also to reform the previous model.

Measures for the Current Performance Appraisal of the Changchun Daily. The current performance appraisal of news reporters of Changchun Daily is divided into two parts which are editor performance appraisal and reporter appraisal and they are classified into the same series to conduct the performance appraisal because of the similarity of them. The performance evaluation 
criteria of the journalists' positions are based on the number of manuscripts and the quality of the manuscript. The specific method of reviewing the number of manuscripts is to calculate the ratio of the total amount of words in the month and the number of journalists in the month. For those who beyond the value or has not yet reached the value to give bonus points or penalty points. The quality of the assessment criteria include: news attention, timeliness, importance, text error rate and several other aspects. The standard of performance evaluation for editorial posts are based on the number and quality of the edited sections per month. Edit layout assessment was designated as A, B, C, D four types, of which A, B for the relatively good quality of the layout and manuscripts, C class level is the error-free, ordinary manuscripts and layout, D class is poor Manuscripts and layouts, where there are more steering errors. The layout of the edit and the grade of the manuscript are directly linked to the salary amount. Changchun daily editorial staff performance appraisal methods implement a combination of monthly and annual, the assessment content and assessment process will be designed and implemented by the evaluation committee, and assessment results take hard work and elimination system combination. The man to be rated as excellent staff, the newspaper office to give recognition and reward; to be rated as unqualified employees, their departments to give warnings and reminders; and those who have been disqualified for two consecutive years will be dismissed.

\section{The Problem and Analysis of the Performance Appraisal of News Reporters of Changchun Daily}

As the launch of performance appraisal, the work enthusiasm for news reporters has been stimulated to some extent, the work achievement has been improved and also getting a good effect.

The Performance Evaluation Criteria are too Profitable. With the growing world economic integration, the competition among the domestic media industries has become increasingly intense. As the organ newspaper and the party newspaper, Changchun Daily not only need to face the test of public opinion, moral construction and content quality, but also to consider the market demand, staff cost, audience perspective and other factors. However, once the media positioning and market demand in conflict, the bad scale grasp will cause deviation: too much to meet the fun of the audience, the content of the vulgar news may get a higher assessment score; paying attention to the ideological and moral construction of the news may not meet the requirements of the interests of the market which will result in the lower performance scores and loss of assessment.

Performance Appraisal Stimulation Guidance is not Appropriate. Performance evaluation is designed to enhance the competitiveness and enthusiasm of the editorial staff, but long-term benefits may lead some editorial employees involuntarily into the trap of personal interests. Driven by the economic interest mentality, part of the editorial staff take the completion of the task as the only direct goal rather than the construction of values and moral; or in order to pursue reading and click rate, turn to seek the content of vulgar and the content which can be written out quickly; or in order to complete the performance appraisal indicators, perform their duty in a perfunctory manner and ignore the quality of manuscripts. There will even be a patch-work manuscript, water injection manuscript and other serious phenomena.

The Feedback of Assessment Criteria are not Timely. Currently, the feedback forms of performance appraisal of the newspaper office are divided into two types: the one is that all the news reporters should participate in the job evaluation and opening the assessment results to the public, the other is that adopting the way of individual notification and personal interview. Whatever either type, they all ignore the feedback part for the assessment results, they cannot communicate with employees in time and help them to improve and transcend themselves. Under such cycle, the pressure in human resource department of press industry will be increased gradually, some employees will treat it negatively and even boycott to participate in the performance appraisal and also the discontent emotion will come over the assessment manager. 
The purpose of performance evaluation is to promote the competitiveness of enterprises, to establish a relatively scientific and fair evaluation mechanism. In order to achieve the goal, this paper puts forward the following ideas:

Establish a System that Combines Performance and Salary. The content of performance appraisal of news reporters should not blindly pursue the number of the articles but to extend to the other aspects, such as article quality, work attitude, moral character, etc. And also the performance appraisal system and reward system that are made on the basis of it will be both restraint and stimulation for news reporters. The evaluation scores can be divided into four hierarchies which are excellence, up to standard, pass muster and fail. For the employees whose scores are excellent continuously, the enterprise should consider them as a future promotion object and give them a certain amount of bonuses to encourage them, for the employees whose scores are qualified, the enterprise should only give them basic wage and for the employees whose scores are very low, the enterprise should transfer or dismiss them.

To Make Index System based on Quantitative Assessment. The performance appraisal standard is made for improving the competitiveness of the enterprise and work enthusiasm of news reporters. If the enterprise blindly pursue the performance standard, the result will definitely turn out to be just the opposite of their wish. The newspaper management department should work out different kinds of evaluation schemes for employees to choose according to the characteristics of different departments and the specialities and abilities of the news reporters. In that way, they won't ignore the article quality because of the pursuit of the number of articles and they will spend more time on detailed interview and show high quality articles to the reader, and thus enhancing the popularity and influence of the newspaper office.

Establish a Sound Performance Appraisal Feedback Mechanism. The establishment of a sound feedback mechanism can help the newspaper human resources department to analyze and compare the results of the examination, and then through the problems reflected by the assessment results to communicate with relevant editors. The excellent results of the performance evaluation of the editors will be praised and get bonus encouragement, on the contrary, poor performance of the staff will be subject to the corresponding punishment. In that way, the company will make reward and punishment clear, let the performance appraisal system and the classification be more distinct, and thus make the editorial staff more understanding of the performance appraisal system, to stimulate their competitiveness to go for a better direction and move forward.

Pay Attention to the Establishment of Incentive Culture System. With the diversification of the media style and the pursuit of a sense of accomplishment of the work, achieving their own value has become the pursuit of more and more editors. Therefore, enterprises should not only pay attention to the material reward of employees, but also cannot ignore the spirit of incentives. Excellent editorial staff should be commended, rewarded and publicized in order to strengthen their sense of responsibility for the job, The new staff should be established the appropriate training programs and career planning to improve their loyalty to the newspaper, which will help to attract outstanding editing talent to stay in the news line, to achieve a win-win situation of the value of editorial staff and the development of the media.

\section{References}

[1] W.B.Kuang, S.M.Qiu and B.Jiang: The Innovation and Thought of Collecting and Editing Assessment Mechanism of News Client[J].Chinese Journalist,2016(5).

[2] H.F.Zhou: Research on Performance Appraisal Method of News Reporters of Press Group [J].Human Resource Development, 2016(2).

[3] N.Xu: Research on the Current Situation of Professional Ethics of News Reporters of Press in our Country [J] New Media Research, 2016(2).

[4] Y.Q.Liu: Discussion on the Challenge of Media Integration Development to Editorial Appraisal[J].Media Observer, 2016(8). 
[5] J.Wang: The Comparative Analysis about the Collecting and Editing Assessment of Newspapers and News Proofreading [J].Journal News Research, 2016(7).

[6] X.T. Zhang: To Improve the Quality of the News Reporters to be a Good Mouthpiece of the Party and People[J]The Chinese and Foreign Entrepreneurs, 2013(07).

[7] Q.X.Zheng: Research on Performance Appraisal Method of Editorial Staff in Newspaper Group [J].Modern Business Trade Industry, 2012(24).

[8] L.Sun: KPI Performance Management System Design Based on the Strategy —-Take Company M as an Example [J]. China Human Resource Development, 2009(05).

[9] Z. Huang: To Look at the Optimization of Appraisal System Issuance from the Profit Maximization of Subject of the Newspaper Office [J].Press, 2007 (6).

[10]L.G.Yin: The regulation Function of Performance Appraisal in Newspaper Collecting and Editing_ Take Southern Daily as the Case Study [J] Press, 2003(04). 